\title{
THE MABEL SMITH DOUGLASS LIBRARY
}

\author{
BY FRANCOISE S. PUNIELLO
}

Ms. Punicllo is Dircctor of the Mabel Smith Douglass Library

In its 74-year existence, the Mabel Smith Douglass Library's various buildings and services have reflected society's definition of the library's role in the educational community and the library's response as the role changed. Some of the changes reflect transformations, such as coeducation, access to education for more of the working class or the decline of smoking; but predominately changes have been a response to the geometric growth of information technology and changes in teaching methodology.

The library was founded in 1918 to serve Douglass College, then the New Jersey College for Women (N.J.C.). At first it had only a few books on loan from the Rutgers University Library which were placed on the Registrar's desk. As the collection grew, books moved to the top of cabinets and in 1919 to a closet in College Hall. Soon two closets were needed. ${ }^{1}$ By 1923 the library was housed in two small study rooms, a stack room and a browsing room on the lower floor of the dean's residence. In 1924 the library was relocated to the top floor of College Hall. This soon was inadequate and in 1926 a wing of Recitation Hall was converted into temporary quarters. The library had open shelves, not a common practice at the time, giving students direct access to books and requiring fewer staff. There was a circulation desk, a reference and reading room, as well as reference, catalog and order departments.

By 1930 the library had again outgrown its space. The 1674 volumes and 8 periodicals owned in 1924 grew to 35,000 volumes and 190 journals ${ }^{2}$ by 1930 . This overcrowding started an intense campaign for an adequate library which would not see fruition until the first phase of the present building was dedicated on April 13, 1961.

The campaign for a new library can be traced through editorials and articles in the college paper. An editorial in the Campus News of November 6, 1931, entitled "The Need for a Library," points out that the New Jersey College for Women is modern and progressive, that it is among the few colleges to present readings for honors, and adds that in order to 
maintain its standards it is necessary to have a library with facilities to match. ${ }^{3}$ In other words, if the library building was not adequate to house the number of users and collections necessary then the educational program of the college could not be carried out.

There were also numerous faculty and administrative reports which expressed the importance of a different and larger building to meet the changes in educational methodology. A "Memorandum Prepared by the Faculty Committee on the Library" 4 states:

"Recent changes in teaching methods-no longer limited to mere text-book study, but now covering extensive reading from numerous sources-have established the library in much closer relation with academic work, and consequently have widened the scope and purpose of the library."

In 1939 Dean Margaret T. Corwin wrote an extensive document to the Rockefeller Foundation, "Request of Financial Aid in Erecting a Library Building for New Jersey College for Women, New Brunswick, New Jersey" in which she restates some of the changes in teaching and how the library must adapt:

In these days of reevaluation of the fundamental policies of the liberal arts college the place of the library is also undergoing a critical review. Decisions about whom to teach, what to teach and how to teach all affect the library to a considerable degree. Changes in admission policy, for example, can be so far reaching as to make a noticeable difference in the reading levels and interests of students. The library is especially sensitive to any curriculum revision, for the addition or withdrawal of courses, particularly the introduction of survey courses, or modification of the elective system will cause noticeable variations in the demand for books. But issues which concern teaching method bear the most direct relationship to the library. The traditional method of presenting subject matter to a class of students called for very little use of books. The trend away from tradition promotes directed reading in place of mere text-book assignments. Practices have now been modified to such an extent that longer reading assignments, class discussions, problem-solving, student-initiated projects and many other devices are used to increase the student's interest. Virtually all such changes in teaching procedure make an increased demand on library resources and facilities. There is a pervasive tendency toward more individualized instruction which is a type of teaching that thrives best on campuses where the library is properly equipped with small studies and seminar rooms. If New Jersey College for Women is to move 
along with the tide of progressive tendencies, its paramount need is for a library building planned specifically for its students and faculty. ${ }^{5}$

She also states that "...a library building, in its very nature, is a structure of a more substantial and permanent character than are laboratories, recitation halls, and residences. Such a building affects the life of the College adversely or for good in proportion as it is adequate or inadequate to serve the objectives of an institution dedicated to education and culture."

By the early forties there were many discussions, meetings, architectural plans, but still no library. The spectre of war made fund-raising difficult. In the introduction to a long report submitted in 1941 to the Trustees of Rutgers University entitled A Library Building - N.J.C.'S Twenty-Fifth Anniversary Goal, J. S. Frelinghuysen is forced to dramatize the students' needs in order to justify an appeal for funds at that time:

At this critical time in world history New Jersey College for Women would turn to its friends for aid only in a case of most urgent need... Totally inadequate facilities for reading rooms and for housing the rapidly growing collection of books has resulted in a condition which cannot but jeopardize the work of the institution if it is allowed to continue. New Jersey College for Women is so strategically placed that any weakness would affect the educational programs of an important region.

These documents detail the importance of a library building to the mission of the college. If the college was to be progressive, then the form and function of the library must be shaped to serve it.

In the mid-forties, Donald F. Cameron, Rutgers University Librarian and frequent guest at Douglass Library planning meetings, shared his expertise in the importance of library buildings. The minutes of the meetings reflect spirited discussions on such topics as individual studies for faculty and/or honor students-interesting in itself because in the 1930 's it had been clarified that the needs for faculty research would be handled by the Rutgers Library. Other topics covered were seminar, reserve, and smoking rooms.

Early in 1946 Keynes Metcalf, Harvard University Librarian and nationally known consultant on library buildings, commented upon the N.J.C. Library plans, stating that cataloging and order departments should be retained. He supported a separate cataloging department which meet a particular need: college libraries, he felt, required simpler 
cataloging, resulting in fewer headings, than those created for a university library. Mr. Cameron disagreed, pointing out that it cost more to build with order and cataloging departments included and that time is wasted when a title is ordered separately for each library. Mr. Metcalf suggested that there was not a great difference in the staff necessary for a combined or unified department catalog department. ${ }^{7}$ This debate, centralized versus decentralized technical services, continues to this day. In fact, the cataloging department was centralized in the mid 1950's and ordering of books was centralized in 1991.

Mr. Metcalf"s main criticism was that the plan was "too old fashioned" with its long reading and reserve rooms with control desks at each end, but agreed with the planned size of 200,000 volumes to serve the working needs of students and faculty. He also thought that for the "sake of efficiency and economy, good messenger service should be established between the Rutgers and N.J.C. libraries." This recommendation was only followed in 1985, when the Rutgers University Libraries Materials Delivery Service was started. ${ }^{8}$

By the 1950 's, there still was no library. A 1954 document entitled "Tentative Draft on Need for a Library at N.J.C. Rutgers UniversityNovember 1954" states that all the problems summarized in the 1941 memorandum were still valid, but the tone was different, advocating plans for a teaching library which would provide books and services that furthered the programs of students and teachers in an undergraduate college. In a June 21, 1957 document entitled "Tentative Estimates on Space Needs of Library Study Center at Douglass College" (prepared by Frances K. Hurley for Mrs. Mary I. Bunting), the insertion of the words "study center" made the library not just a repository for books, but a center for curriculum assistance that integrated classroom activities as well as reserve readings and listening facilities. The concept of user services was now an integral part of library philosophy. The document lists the library's functions, stating that:

The library should provide guidance to individuals either in finding information in books or in selecting books as the need arises.

The library should provide instruction to groups in the use of its resources from freshmen orientation to senior honor projects.

The Library should provide varying patterns in places to read, such as conventional tables and chairs, informal 
arrangements of lounge chairs, individual carrels or rooms for group study. The spaces should be large enough that students may either use their own or library materials.

Therefore the future building must have spaces to assist and teach users. These included, in addition to reference areas, spaces where classes in bibliographic instruction could be provided.

By 1958 there still was no library. The May 20, 1958, Newark StarLedger article entitled "The Girls They Turn Away..." recognized the conditions at the library as one of the reasons that admissions were held down. New dormitories had been built but there was a lack of classrooms because the library was still housed in the Recitation Building, a building intended solely for classrooms. The dormitory rooms were doubles allowing no room for desks, which, coupled with lack of study space at the library affected enrollment. ${ }^{9}$

Final plans for the library were projected to serve Douglass College's 2000 undergraduates and faculty. The firm Warner, Burns, Toan, Lunde were contracted to design the building with Eleanor Larrabee as the Project Manager. Finally on April 3, 1961, the library was opened. It was financed by an appropriation of $\$ 1,000,000$ from the New Jersey State legislature and by $\$ 75,000$ given to the College by alumnae and friends.

In an interview, Larrabee stated that there was no preconceived idea of how the building should look, but that the Trustees of the University were of two minds. Some advocated a colonial building complementing the architecture of the campus while others were open to other suggestions. In either case, there was concern that Voorhees Chapel should not be obscured or overpowered. An article in Progressive Architecture entitled "College Libraries: Bridges to Learning"10 describes how the Douglass Library architect used the steep grade down a ravine to construct a three level structure that appears low and thus dramatizes the height of the chapel (see Figure 1). The mansard roof, which Larrabee says was the first one constructed in modern times, minimizes the height of the library. The roof contains the mezzanine level and the two-story ceiling over the two main reading rooms. The roof is leadcovered copper, which is rich and yet unobtrusive in color. The bricks on the exterior were chosen to blend with the chapel: pink with flemish bond and white stone. The fenestration (the dimensions between the vertical supports) mimics the elegance of an 18th Century building, reflecting the same proportions as Old Queens, the colonial administration building on the Rutgers College Campus. The air-conditioned 
open stack library was 184 feet long by 94 feet wide, with a total enclosed space of approximately 41,000 square feet. The attractive interior used brick screen walls, filigree wood panels, wood, and concrete. It had a book capacity of 150,000 volumes and seated 600 students. The building design won an award from the American Institute of Architects, the American Library Association and the National Book Committee in 1963. The library's innovative use of stacking was used by the Estey Corporation in its advertisements (see Figure 2).

On the main floor was the Mabel Smith Douglass Room which housed music and art books, current periodicals, new book displays and Mabel Smith Douglass memorabilia. Also on the main floor was a general reading room, including reserve and reference books, as well as the card catalog, and a central service core. In this core was the office of the librarian, the technical services department, the circulation department, and the reference department. The prevailing management philosophy, stressing the importance of staff supervision, was responsible for this very tightly organized space.

The East Room, West Room, twelve individual study rooms, four rooms for group study and typing and staff room and workroom were located on the ground level. There was an outside reading deck at the back which was connected by a bridge from the main floor gallery. The deck hid the transformer vault on the level below and provided cover for the delivery entrance to the building. The mezzanine housed the faculty reading room and, according to Larrabee, was originally intended to be an art room. The skylights not only illuminated art reproductions in books but also minimized energy costs.

Light was a very important design consideration. Larrabee wanted as much natural lighting as possible because of its quality. Therefore she designed large windows, floor to ceiling on the main level, with a large overhang to shade them. Daisy Shenholm, director of the Mabel Smith Douglass Library from 1970 to 1987 , stated that libraries were previously built with small windows since the light was thought to destroy books and patrons would be distracted by looking out the windows. Larrabee designed one of the first college libraries to let in the light and protect the books by placing them in the center of the room and putting the carrels and lounge furniture at the perimeter.

There were several smoking areas in the library for patrons. These included the East Room, the group studies, the individual studies and the Mezzanine. Today there are no smoking areas for the public, nor is 
smoking permitted anywhere in the entire building-a reflection of a change in our society.

There were different seating areas in the building as well as carrels. Larrabee designed the carrels (see Figure 3). It was her idea to group them in two's. She calls this an architectural conceit. She never copyrighted the design and it has since been copied by others. The carrels were designed high enough for privacy, but low enough so people could see over them. There was a shelf for books and a coat hook. Book bins were provided in the corridor on the ground floor as well.

The design and concept of the building was very much in keeping with the objectives of undergraduate libraries outlined by Irene A. Braden in The Undergraduate Library. These include:

Providing open access to the collection to avoid the difficulties of the closed-stack system.

Centralizing and simplifying services to the undergraduate.

Providing services additional to those given by the research collection.

Constructing a building with the undergraduates use in mind. ${ }^{11}$

The Douglass Library of 1961 satisfied these objectives. There were seating areas to accommodate the different types of users (see Figure 4). There were group study tables, individual studies and small group studies. There were also comfortable lounge seats placed in different areas for students who liked to study where there is a lot of activity and for those who require quiet.

The 1961 building was built to accommodate the growth of Douglass College, but no one had correctly estimated the explosive growth that would occur in undergraduate education in America in the 1960s. Post World War II saw the expansion of college education to a greater percentage of the population which now included children from working class families helped in part by the G.I. Bill and the opening up of community colleges, colleges, and universities. By the late 1960's the enrollment at Douglass College had nearly doubled and the new library was already inadequate. Therefore plans were made for an addition. By the time this addition was built in 1975, Cook College had been created and the responsibility for service to these science students was added. Therefore, on the dedication day of the addition, the building was already inadequate.

The architectural firm of Warner, Burns, Toan, Lunde was again retained and Eleanor Larrabee was again the Project Manager. The new 
addition was placed at the back of the library so that the front looked unchanged. A primary consideration was that the view of the ravine not be obscured. Larrabee, ever concerned with light and views, built the addition so that from the main level you look down into the ground level through clerestory windows and into the ravine. The result is an addition and original building which are very successfully integrated: the ground level is completely opened, connecting the West Room of the original building and the periodical room and the large staircase runs the height of both sections.

What changed at Douglass College and in higher education between 1961 to 1975 that led to changes in the building? The college had become less of a commuter school and more residential. Larrabee and Shenholm both say that the dormitories were also just too noisy. Therefore more seats, carrels, tables, and large free form carpeted steps were added (see Figure 5). Larrabee saw these free form steps as being for short term use by students, not as an area where patrons were encouraged to linger. Another change was that there were no longer the bins necessary for commuter students to keep their materials.

In the intervening years the use of media in the higher education process had increased. The original building had one phonograph in a lounge. Now there was a need for a full-scale media department to house slides, records, audio visual kits, and video. There were 12 video stations for students to view tapes. Students were encouraged by professors to hand in audio visual productions in place of papers, and the library assisted them in this endeavor by helping them produce slides.

Another sign of changing times was that theft prevention technology had to be introduced to address the increasing problem of pilferage. A $3 \mathrm{M}$ Tattletape security system was integrated into the design of the foyer. Another technology which had become important to students was the use of photocopiers, so additional space was provided for more machines. The use of microform machines increased because in some instances microforms are cheaper than a paper copy; moreover, they take up less space and are not stolen or destroyed as often as periodicals. All these increased technologies led to conflict of function over form. How to successfully integrate them into an existing building were a part of constant discussions.

Philosophical changes in the 60s and 70 s had an impact. During this period the conviction grew that an undergraduate library should expose students to a variety of cultural experiences. Since 1971, the Douglass Library has had a series of women artists shows. To accommodate them 
the front lobby was designed to be used as an exhibition space. Further, local management philosophy had abandoned the theory that employees must be continually monitored. The centralization of library function, therefore, was no longer required which is reflected in the technical services department moving to the rear of the new wing.

The cost of the addition was $\$ 1,895,000$. What made it particularly expensive, according to Larrabee, was a $\$ 5$ surcharge per square foot to remove a large water line that ran down the back of the site. The building was doubled in size. There were now 1025 seats and room for 215,000 volumes.

The Mabel Smith Douglass Library also became the undergraduate library for Mason Gross School of the Arts after its creation in 1976 and in 1982 the Music Research Library for the University was moved from Alexander Library to the Ravine Room in the Douglass Library. That move required that 50,000 volumes from the Douglass Library collection be put into storage. In 1991 the library was given additional collection development roles: it now houses the primary collections for women studies, theater arts, dance, visual arts, speech and exercise science for the entire university.

These role changes again challenge us to plan for additional space. Besides inadequate space for staff, collections and services another problem is that the library and addition were all constructed prior to the recent revolution in electronic information technology. Particularly the reference area must be retrofitted to accommodate these new resources. An electronic classroom with a bank of computers is also required to assist and train our students to navigate the many electronic resources.

Both wings of the existing Douglass Library are beautiful, well designed and functional. The library has responded in its 74-year existence to the changes in society and educational theory. As we shift as a society into the information age, the next building design will once again have to change to meet new needs.

\section{Notes}

1 "L ibrary Handbook for Students; New Jersey College for Women" (New Brunswick, N.J.: New Jersey College for Women, 1939), 7-8.

${ }^{2}$ Ada English. "Library" in New Jersey College for Women, Annual Reports, 1930, (New Brunswick, N.J.: Rutgers University, December 1930), 111-116.

${ }^{3}$ Campus News 6 November 1931, 1-2.

${ }^{4}$ Memorandum Prepared by the Faculty Committee on the Library (n.d. probably 1939 or 1940). 
5 Margaret ' $T$. Corwin, "Request of financial aid in Erecting a Library Building for New Jersey College for Women." (New Brunswick, N.J.: New Jersey College for Women, 1939) Section VI, 6-7.

${ }^{6}$ Ibid, Section VI, 1.

7 "Notes on the Meeting of the Library Committee held on Saturday, February 9 , 1946, in Miss Corwin's Office and I ater at I Icr Home" 1-2, carbon copy.

${ }^{8}$ Ibid.

${ }^{9}$ Newark Star Ledger 20 May 1958, 1-2.

10 "College Libraries: Bridges to Learning." Progressive Architecture 44 (March 1963) 134-141.

11 Irene A. Braden, The Undergraduate Library. ACRL, Monograph No. 31. (Chicago: American Library Association, 1970) 2. 


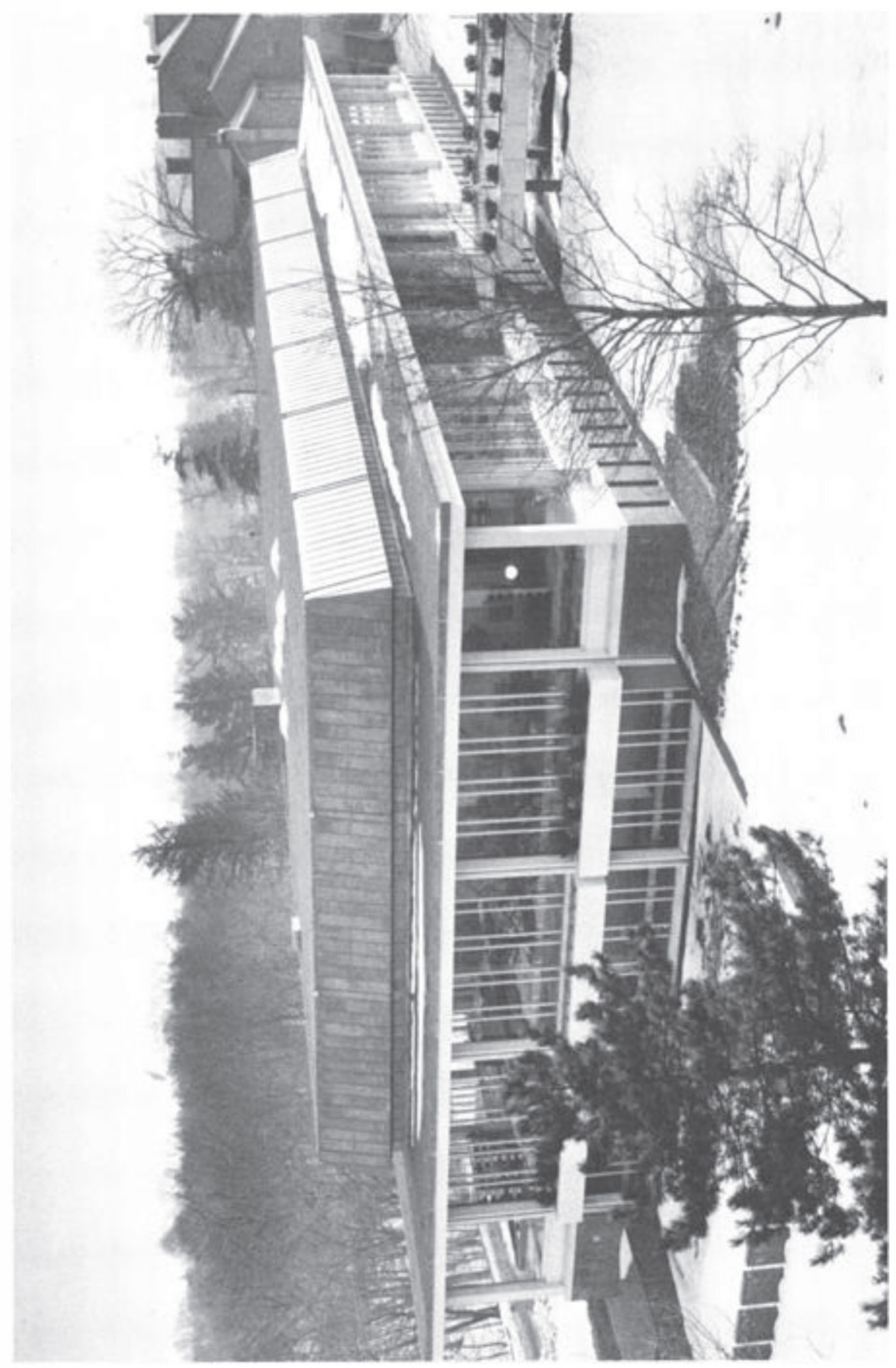

Fig. 5.1 Mabel Smith Douglass Library Phase I, 1961 (Photograph: F.G. Higgins) 


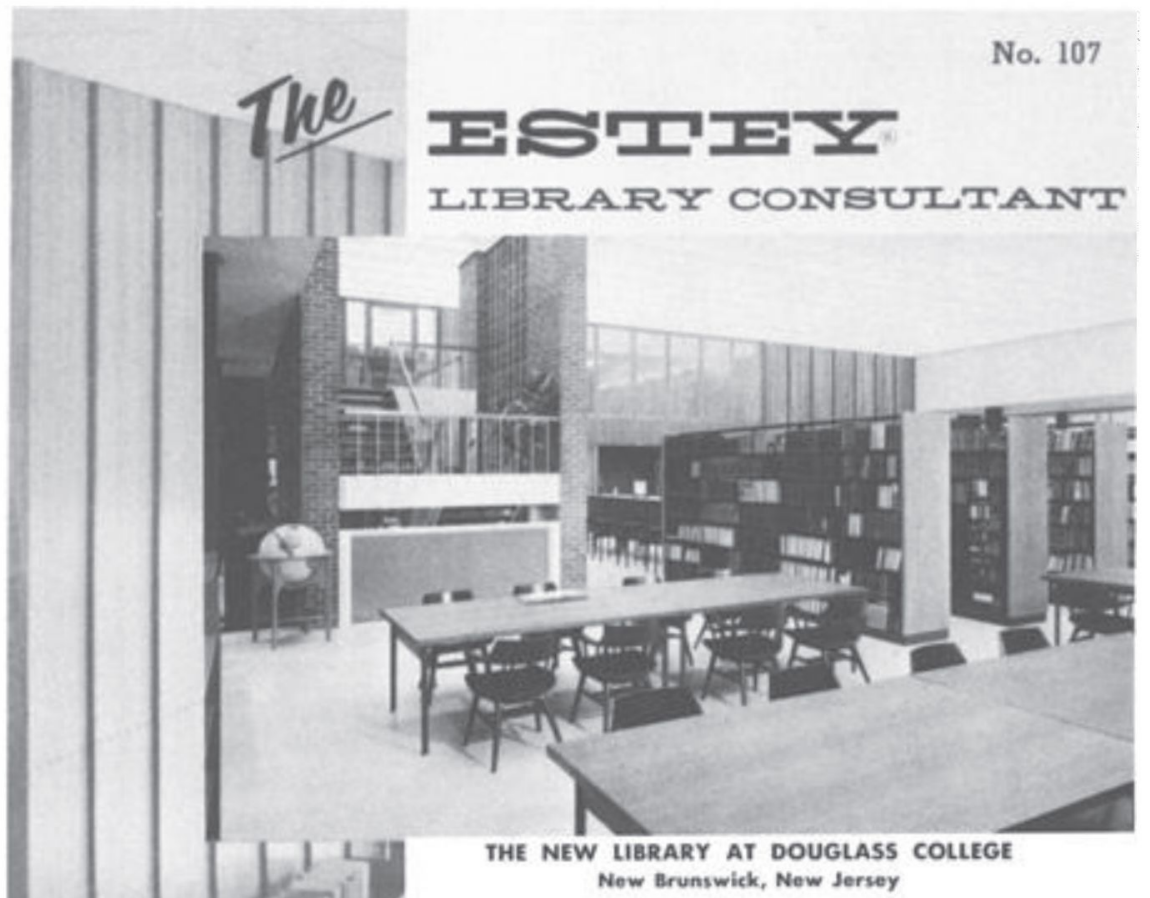
mest were wed to ockieve the simple beouty of this moders library. The arekiects planned and supervised every aipect of the interior.

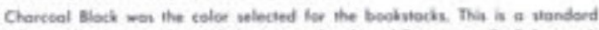

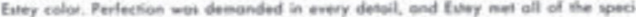
ficotism. The deciorative ook end posels were alvo wpplind by Evor.

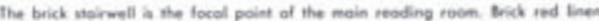
is uned on portions of the mall. Wood poneling os the interier woll is occented by the block pilowen of the Esiey wollfenoshed thelving. which estend is feet bigh thom hoer to ceiliag.

An enterse bridge spons the ruvine aurounding the Itrany. Windoe moll on

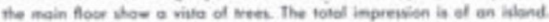

Devglons Cellege in the wonen's cellege of tutpers, The State Univening of New

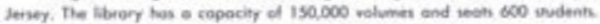

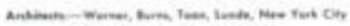

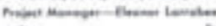

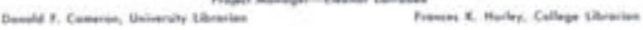

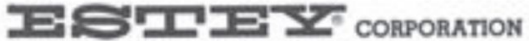

ONE CATHERINE STREET, RED BANK, N. J.

C. wh tant coes

Fig. 5.2 Estey Corporation Advertisement Featuring the Mabel Smith Douglass Library, 1961 


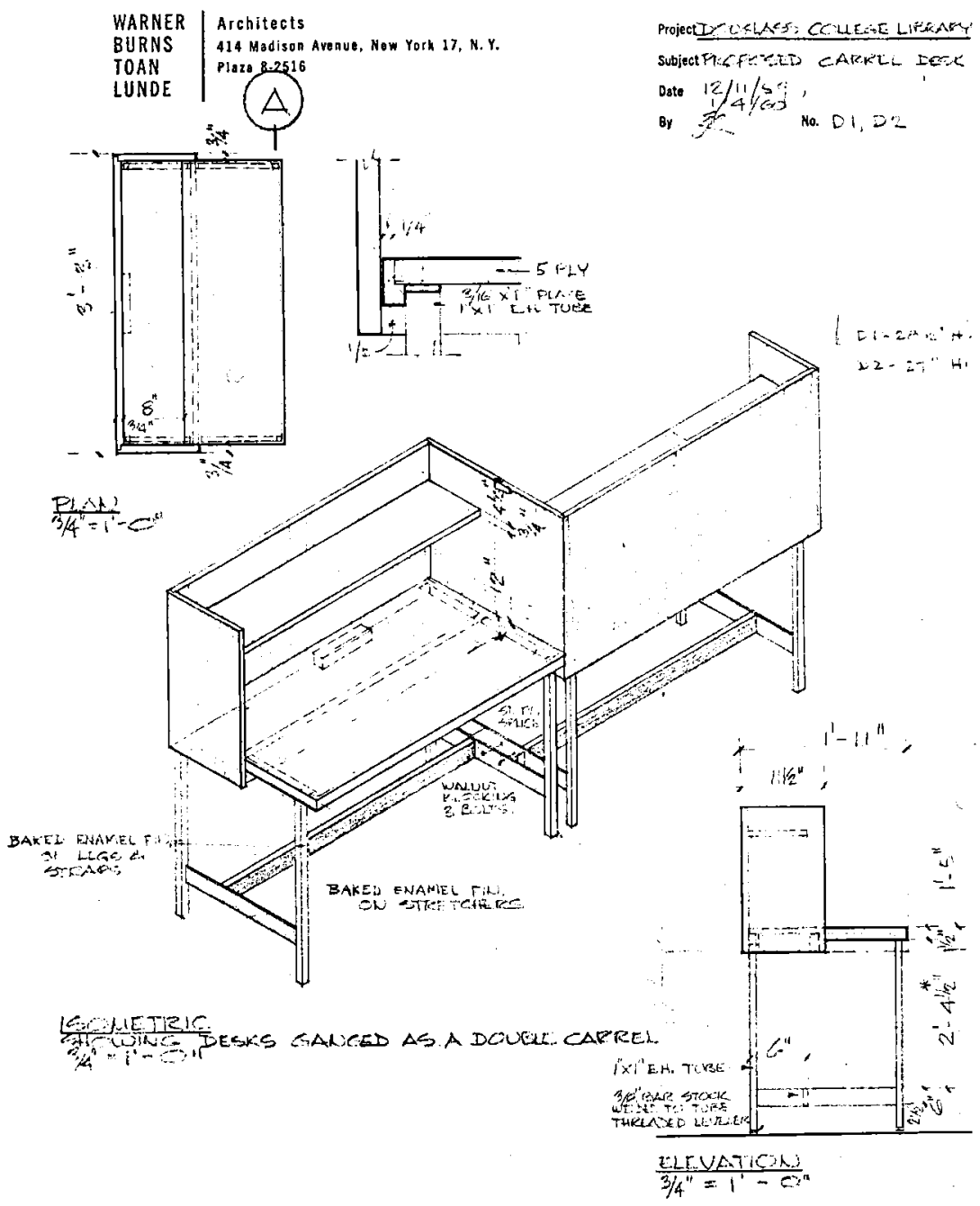

Fig. 5.3 Carrel Specifically Designed for the Mabel Smith Douglass Library by Eleanor Larrabee 


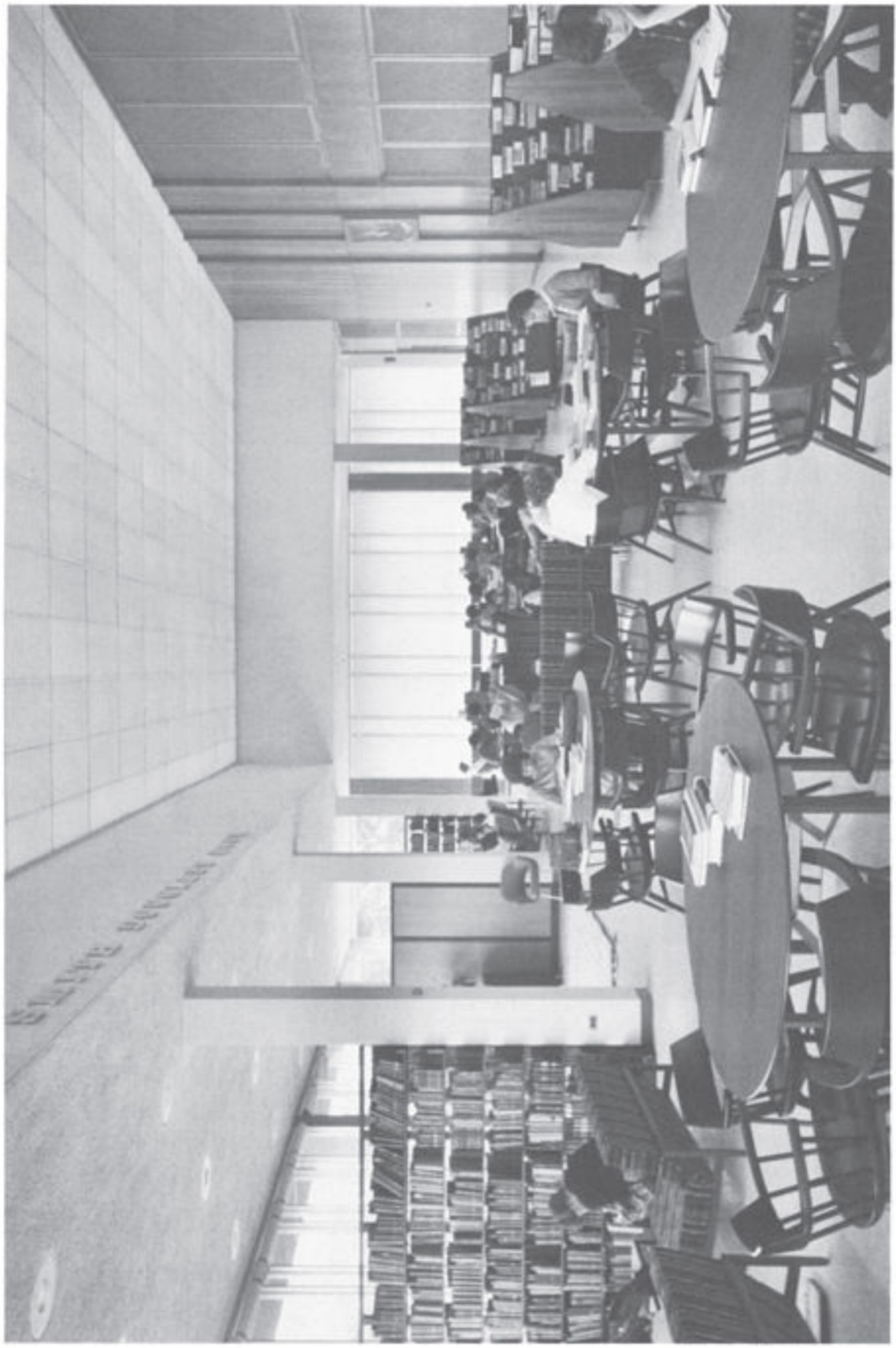

Fig. 5.4 Mabel Smith Douglass Library Phase I-Mabel Smith Douglass Room (Photograph: Gottscho-Schleisner, Inc.) 


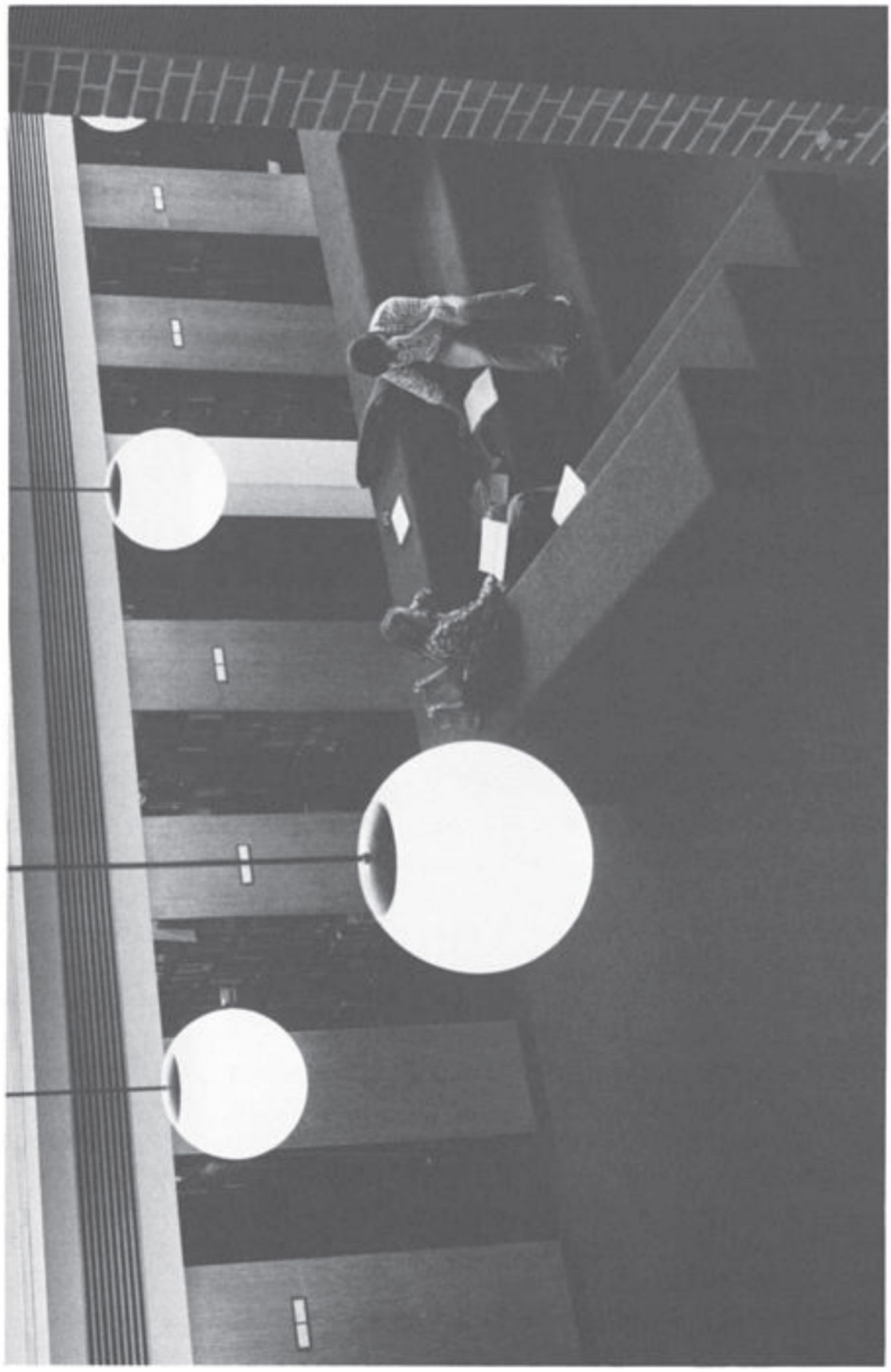

Fig. 5.5 Mabel Smith Douglass Library Phase II-Tapestry Room 